\title{
Resistance of the marine diatom Thalassiosira sp. to toxicity of phenolic compounds
}

\author{
Charles R. Lovell ${ }^{1, *}$, Niels T. Eriksen ${ }^{2, * *}$, Alan J. Lewitus ${ }^{2,3}$, Yung Pin Chen ${ }^{1}$ \\ ${ }^{1}$ Department of Biological Sciences and ${ }^{2}$ Belle W. Baruch Institute of Marine Biology and Coastal Research, \\ University of South Carolina, Columbia, South Carolina 29208, USA \\ ${ }^{3}$ Marine Resources Research Institute, South Carolina Department of Natural Resources, Charleston, \\ South Carolina 29412, USA
}

\begin{abstract}
In many nearshore marine systems, microalgae can be chronically exposed to anthropogenic and biogenic phenolic and halophenolic compounds that accumulate in surficial sediments. Although biodegradation of some phenolic compounds has been demonstrated in freshwater algae, this capability has not been tested in marine species. We examined a ubiquitous marine diatom, Thalassiosira sp. HP9101, for its capacity to tolerate, and/or utilize phenol and benzoic acid. We also examined the aromatic ring cleavage reactions of this diatom and its capacity to dechlorinate chlorophenolic compounds. Axenic Thalassiosira sp. cultures were grown at $60 \mu \mathrm{E} \mathrm{m}{ }^{-2} \mathrm{~s}^{-1}(12: 12 \mathrm{~h}$ light:dark cycle) in the presence or absence of phenol, benzoate, catechol or protocatechuate and their growth kinetics and physiological responses determined. Thalassiosira sp. was inhibited by catechol and protocatechuate. Growth in the presence of $1 \mathrm{mM}$ phenol was observed only after an extended lag and was quite slow. Growth in the presence of $0.25 \mathrm{mM}$ phenol occurred after a much shorter lag and phenol was taken up by these cultures at an estimated rate of $0.08 \mathrm{fmol}^{\text {phenol cell }}{ }^{-1}$ $\mathrm{h}^{-1}$. No inhibition of Thalassiosira sp. by $1 \mathrm{mM}$ benzoate was observed. Growth stimulation by added phenolic substrates was not demonstrated, although phenol-supplemented Thalassiosira sp. produced substantial levels of protocatechuate 3,4-dioxygenase and protocatechuate 4,5-dioxygenase, the ortho- and meta-pathway aromatic ring cleavage enzymes, respectively. Only protocatechuate 4,5-dioxygenase activity was detected in Thalassiosira sp. grown with $1 \mathrm{mM}$ benzoate. Phenol supplemented Thalassiosira sp. was also capable of dechlorinating monochlorophenols, 3,5-dichlorophenol, and 2,4,6-trichlorophenol. These reactions were NADH-dependent and were not observed in control cultures grown without phenol.
\end{abstract}

KEY WORDS: Benthic microalgae $\cdot$ Marine diatom $\cdot$ Phenol $\cdot$ Aromatic ring cleavage $\cdot$ Haloaromatics Dehalogenation

Resale or republication not permitted without written consent of the publisher

\section{INTRODUCTION}

Phenolic compounds are important products of the petrochemical and coal-processing industries (Reisch 1994), and are common pollutants in many nearshore marine systems. These compounds are also produced

\footnotetext{
*E-mail: lovell@biol.sc.edu

${ }^{* *}$ Present address: Department of Life Sciences, Aalborg University, Sohngaardsholmsvej 49, 9000 Aalborg, Denmark
}

naturally through breakdown of lignin (Wilson et al. 1986, Goni \& Thomas 2000, Motamed \& Texier 2000), which is often abundant in estuarine sediments. Other types of phenolic compounds that can be found in nearshore marine systems include a variety of halophenols. Chlorinated phenolic compounds, such as chlorophenols, chloroguiacols, and chlorocatechols, have numerous anthropogenic sources, including pulp mill effluent (Kringstad \& Linström 1984, Xie et al. 1986, Häggblom \& Salkinoja-Salonen 1991), agricul- 
tural and residential runoff (Ahlborg \& Thunberg 1980), and sewage and wastewater discharges (Chapman et al. 1996). In addition, bromophenolic compounds are natural products of a variety of marine organisms including many species of marine macroalgae (reviews by Butler \& Walker 1993, Gribble 1999) and infaunal polychaetes and hemichordates (Woodin et al. 1987, Chen et al. 1991, Woodin 1991, Steward et al. 1992, 1995, Fielman et al. 1999, Gribble 1999). These anthropogenic and biogenic phenolic and halophenolic compounds can accumulate to significant levels in surficial sediments (Karickhoff et al. 1979, Schellenberg et al. 1984, King 1986, Xie et al. 1986, Lincoln et al. 2002), and at least some of these compounds, at concentrations found in sediments, are demonstrably toxic to some of the sediment biota (Woodin 1991, Woodin et al. 1993, Fielman et al. unpubl. data).

Steward et al. (1992) demonstrated that elevated bromophenol concentrations produced by the infaunal marine polychaete Notomastus lobatus were not inhibitory to benthic microalgal populations associated with exposed sediments in the North Inlet estuary, a salt-marsh estuary near Georgetown, South Carolina, USA. The authors concluded that the microalgae were capable of resistance to halophenol toxicity. Information on the physiological mechanisms underlying microalgal resistance to these and other phenolic compounds may have relevance to ecosystem function, because acute or chronic exposure to such compounds may be common to not only benthic microalgae but to planktonic types that, for example, are intimately associated with resuspended sediments. A pressing question is whether metabolic degradation may play a role in resistance of microalgae to toxicity of phenolic and halophenolic compounds.

Recent studies have shown significant biodegradation of phenol and its methylated homologues by the freshwater mixotrophic chrysophyte Ochromonas danica (Semple \& Cain 1996, 1997, Semple et al. 1999). In addition, an unidentified freshwater microalga has been found to tolerate high levels of pentachlorophenol and to produce $\mathrm{CO}_{2}$ from this compound (Tikoo et al. 1997). We have examined a marine diatom, Thalassiosira sp. HP9101, for its capacity to tolerate and to degrade phenolic compounds. Thalassiosira spp. are ubiquitous and often numerically abundant in marine systems, with over 100 species described from diverse marine environments (Round et al. 1990, Gedde 1999). Also, Thalassiosira spp. were a relatively abundant component of the nanophytoplankton in North Inlet (Lewitus et al. 1998), a shallow well-mixed estuary marked by high tidal scouring. We therefore consider Thalassiosira sp. HP9101 an appropriate model species representative of microalgae that can be intimately associated with resuspended sediments.
As a first step towards testing the potential for marine microalgae to degrade phenolic compounds, we examined the physiological and metabolic responses of Thalassiosira sp. to phenol, catechol, protocatechuate, and benzoate additions. We also examined this organism for metabolic activities needed for degradation of chlorophenols. We employed chlorophenols in this study due to their widespread occurrence in nearshore marine sediments and their recalcitrance relative to their brominated homologues.

\section{MATERIALS AND METHODS}

Culture source and growth conditions. Thalassiosira sp. HP9101 (Bacillariophyceae) was isolated in 1991 by A.J.L. from the Choptank River, a subestuary (salinity 7 to $12 \mathrm{ppt}$ ) of Chesapeake Bay. The culture was made axenic by aseptically picking a single cell using a capillary pipette, followed by cultivation. Batch cultures were maintained in a temperature-controlled environmental chamber $\left(26^{\circ} \mathrm{C}\right)$ in $\mathrm{f} / 2$-enriched filtered seawater as in Guillard 1975, but without Si addition), adjusted to $17 \mathrm{ppt}$ by dilution with ultrapure deionized water. Cultures were acclimated to growth at $60 \mu \mathrm{E}$ $\mathrm{m}^{-2} \mathrm{~s}^{-1}$ (12:12 $\mathrm{h}$ light:dark cycle) by repeated transfers from mid-exponential growth phase, following Lewitus \& Kana (1994). After acclimation to the growth irradiance, aliquots were transferred into new medium ( $\mathrm{n}=2$ for Expt $\mathrm{A}, \mathrm{n}=3$ for Expt B), with or without phenolic compound addition, at an initial population density of $5 \times 10^{3}$ to $5 \times 10^{4}$ cells ml $^{-1}$, depending on the experiment. Culture purity was confirmed in all experiments by periodic testing (including at the end of the experiment) using a DAPI-staining technique (Porter \& Feig 1980).

Experimental protocols. The purpose of the first experiment (Expt A) was to determine if ring cleavage dioxygenase or reductive dechlorinase activity could be measured in Thalassiosira sp. HP9101, and whether these enzyme activities required the presence of phenolic compounds in the culture medium (i.e. were potentially inducible by phenolic substrates). Chlorophenols were not used as supplements due to their toxicity, volatility, and low solubility in seawater. Aliquots of Thalassiosira sp. culture were transferred into replicate 11 polycarbonate bottles containing medium with or without $1 \mathrm{mM}$ phenol, $1 \mathrm{mM}$ catechol, or $1 \mathrm{mM}$ protocatechuate, at initial population densities of $5 \times$ $10^{3}$ cells $\mathrm{ml}^{-1}$. After a $5 \mathrm{~d}$ period of exposure (that allowed an initial period of acclimation), aliquots from these cultures were again transferred to new medium to re-establish initial population densities of $5 \times 10^{3}$ cells $\mathrm{ml}^{-1}$. Cultures in experimental treatments, but not controls, experienced lags in growth. All cultures exhibit- 
ing active population growth were harvested in exponential growth phase (verified by continued timecourse cell counts of the remaining culture) at cell abundances ranging from $5 \times 10^{5}$ to $1.5 \times 10^{6}$ cells ml $^{-1}$. Cell abundance was monitored using a hemocytometer, following Lewitus et al. (1998).

Based on the relatively high dioxygenase and dechlorinase activity measurements from phenol-grown Thalassiosira sp. cultures in the first experiment, a follow-up experiment (Expt B) was designed to further examine the effects of phenol (concentration range from 0.01 to $1 \mathrm{mM}$ ) on the growth rate, chlorophylla cell $^{-1}$, biovolume, and dechlorinase activity of the diatom. We also tested $1 \mathrm{mM}$ benzoate as another potential phenolic substrate. Chlorophyll a was measured by fluorometric analysis, following extraction in $90 \%$ acetone using a freeze-thaw method (Glover \& Morris 1979). Biovolume was calculated by capturing images with an image analyzer, and calculating cell volume as $\pi \mathrm{r}^{2} \times$ length. Biovolume estimates were based on sample sizes of 12 to 13 cells at $0 \mathrm{~h}$, or from 21 to 78 cells at other sampling times. Phenol or benzoate concentrations in the culture medium were followed by HPLC analysis of culture supernatants, taken at the same times as cell abundance was measured ( 1 to 3 d intervals). Culture samples $(1 \mathrm{ml})$ were mixed with an equal volume of $100 \%$ acetonitrile. After centrifugation to remove precipitated proteins and polysaccharides, the samples were assayed for phenol or benzoate using a Hewlett Packard 1100 series HPLC system with a $15 \mathrm{~cm}$ HP C18 reversed-phase column and using a methanol: $\mathrm{H}_{2} \mathrm{O}$ :acetic acid (50:49:1) mobile phase at a flow rate of $1.5 \mathrm{ml} \mathrm{min}^{-1}$. Detection was by absorbance at $280 \mathrm{~nm}$. The retention times of phenol and benzoate from the cultures were identical to those of the authentic compounds. Compound quantification was based on absorbances of known quantities of phenol and benzoate.

Ring cleavage dioxygenase and dehalogenase activity assays. Thalassiosira sp. cells grown with phenol or benzoate were homogenized by sonication. The homogenate was centrifuged at $5000 \times g$ for $5 \mathrm{~min}$ and the supernatant designated as crude extract. Catechol 1,2-dioxygenase activity (Nakazawa \& Nakazawa 1970), catechol 2,3-dioxygenase (Nozaki 1970), protocatechuate 3,4-dioxygenase (Fujisawa 1970), and protocatechuate 4,5-dioxygenase (Ono et al. 1970) were assayed using established methods. Dechlorination of various chlorophenols by Thalassiosira sp. crude extracts was measured using a reaction system consisting of $10 \mu \mathrm{M} \mathrm{NADH}, 50 \mu \mathrm{g} \mathrm{ml}^{-1}$ 2,4,6-trichlorophenol, 3,5-dichlorophenol, or 2-, 3-, or 4-chlorophenol, and $50 \mu \mathrm{g} \mathrm{ml}^{-1}$ crude extract protein in $100 \mathrm{mM} \mathrm{KH}_{2} \mathrm{PO}_{4}$, $\mathrm{pH}$ 4.6. Assay mixtures were incubated at $28^{\circ} \mathrm{C}$ for $15 \mathrm{~min}$ and the reactions stopped by addition of an equal volume of acetonitrile. After centrifugation, the samples were assayed for chlorophenols using the HPLC system described above and following the methods of Watson et al. (2000). Retention times of dehalogenation products were compared to those of authentic standard compounds and compound quantification was based on absorbance of known quantities of authentic compounds. One unit of enzyme activity is defined as $1 \mu \mathrm{mol}$ of substrate consumed per minute. Protein was assayed by the method of Lowry et al. (1951).

\section{RESULTS}

\section{Effects of phenolic compounds on growth, biovolume, and chlorophyll a}

In Expt A, growth was inhibited in 2 treatments (1 $\mathrm{mM}$ catechol or $1 \mathrm{mM}$ protocatechuate, data not shown) and never recovered throughout the experiment $(112 \mathrm{~d})$. In the $1 \mathrm{mM}$ phenol treatment, a pronounced lag in growth occurred (82 d), followed by slow growth $\left(\mu=0.07 \mathrm{~d}^{-1}\right)$. Because phenol concentrations were not followed in Expt A cultures, it is unknown whether the end of the growth lag was due to the development of increased tolerance (e.g. acclimation) to $1 \mathrm{mM}$ phenol or to a decrease in phenol concentration (e.g. through chemical conversion or uptake by Thalassiosira sp.).

Expt B tested the physiological response of Thalassiosira sp. to phenol or benzoate additions in shorterterm incubations (maximum $14 \mathrm{~d}$ ) than Expt A. The highest phenol concentration tested (1 mM) inhibited growth throughout the course of the experiment (Fig. 1A,B), consistent with the 82 d growth lag observed in Expt A. The mean biovolume of the phenolenriched cultures was higher than that of the controls, but not significantly so (Student's t-test, $p>0.05$ ) due to high variability of cell size in this treatment (Fig. 1C). The reason for the relatively high cell size variability in $1 \mathrm{mM}$ phenol-treated cells was that a portion of the population was elongated (Fig. 2) and appeared as if cell division, but not biosynthesis, was repressed. In contrast to the response to $1 \mathrm{mM}$ phenol, cultures grown with $1 \mathrm{mM}$ benzoate in the medium were not inhibited and, in fact, cell abundance (i.e. growth rate), chlorophyll $a$, or biovolume in the benzoate-enriched cultures did not differ significantly ( $t$-test, $\mathrm{p}>0.05$ ) from the controls.

The inhibitory effect of phenol on Thalassiosira sp. growth rate increased with increasing phenol concentration, with a threshold for significant inhibition at about $0.3 \mathrm{mM}$ phenol (Fig. 3). Although population density decreased during incubation after 1.0 or 

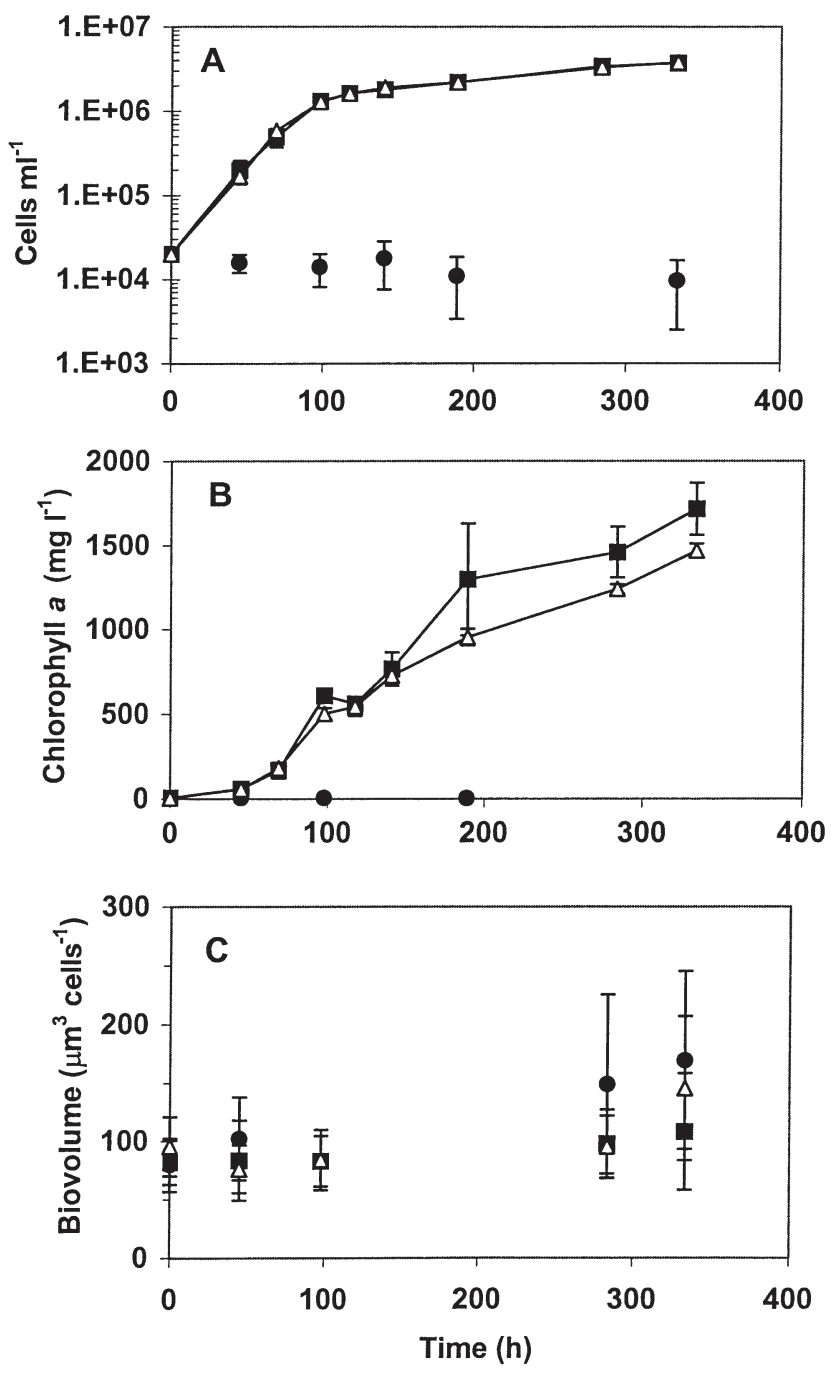

Fig. 1. Thalassiosira sp. Time-course changes in (A) cell abundance, (B) chlorophyll $a$, and (C) biovolume of control ( $\square$ ), $1 \mathrm{mM}$ phenol $(\bullet)$, or $1 \mathrm{mM}$ benzoate $(\Delta)$

$1.1 \mathrm{mM}$ phenol addition (mean specific growth rate of $-0.065 \mathrm{~d}^{-1}$ ), the mean specific growth rate of cultures grown with 0.3 to $0.4 \mathrm{mM}$ phenol was $0.66 \mathrm{~d}^{-1}$, only $40 \%$ less than that of control cultures. The growth rates of cultures enriched with phenol at concentrations less than $0.3 \mathrm{mM}$ did not differ significantly ( $t$-test, $\mathrm{p}>0.05$ ) from the rates of control cultures.

In cultures grown with $0.25 \mathrm{mM}$ phenol, a short lag in population doubling consistently occurred, followed by growth at rates similar to control cultures (e.g. Fig. 4A). Chlorophyll a cell ${ }^{-1}$, however, varied significantly ( $t$-test, $\mathrm{p}<0.05$ ) with this treatment (Fig. 4B). Initially, cellular chlorophyll content was higher in the phenol-enriched cultures, corresponding to the lag phase. Afterwards, chlorophyll a cell ${ }^{-1}$ decreased in the phenol treatment, and remained at a significantly

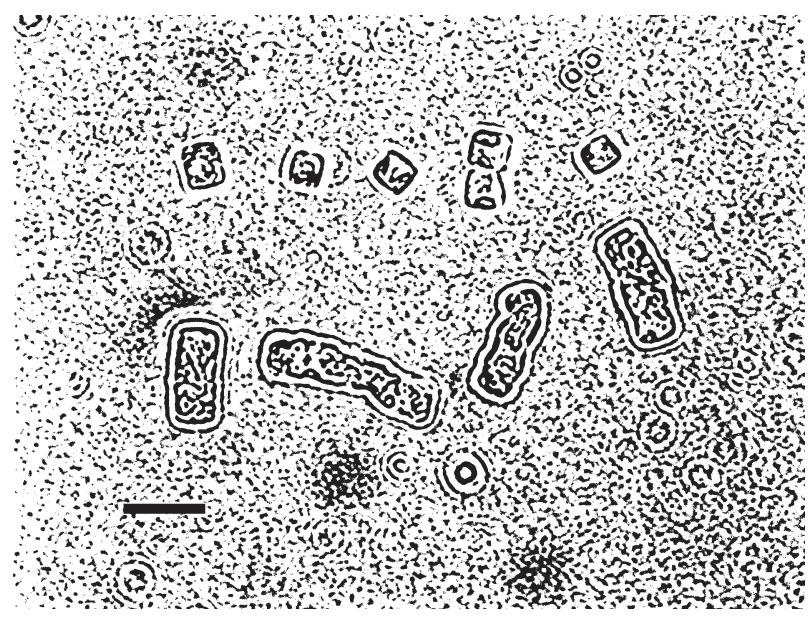

Fig. 2. Thalassiosira sp. Superimposed light micrographs of cells from 2 cultures. The 6 smaller cells at the top were taken from a control culture (no phenolic compound addition), and the 4 larger cells from a culture grown with $1 \mathrm{mM}$ phenol. Both samples were taken at $336 \mathrm{~h}$ of the experimental incubation. Scale bar $=5 \mu \mathrm{m}$

lower level ( $t$-test, $\mathrm{p}<0.05)$ than in control cultures throughout the experiment. Mean biovolume was not significantly different $(t$-test, $\mathrm{p}>0.05)$ between treatments (data not shown).

In cultures grown with $0.1 \mathrm{mM}$ phenol, a time-course decrease in ambient phenol concentration was measured during the period of increased cell abundance (Fig. 5). Using a weighted average for population density (Frost 1972), the phenol uptake rate during the period of decreasing phenol concentration was estimated as 0.08 fmol phenol cell ${ }^{-1} \mathrm{~h}^{-1}$.

\section{Production of ring cleavage dioxygenases}

The capacity of the diatom to degrade phenol and other phenolic compounds was assessed by assay of enzymes involved in cleavage of the aromatic ring. Thalassiosira sp. grown in the presence of $1 \mathrm{mM}$

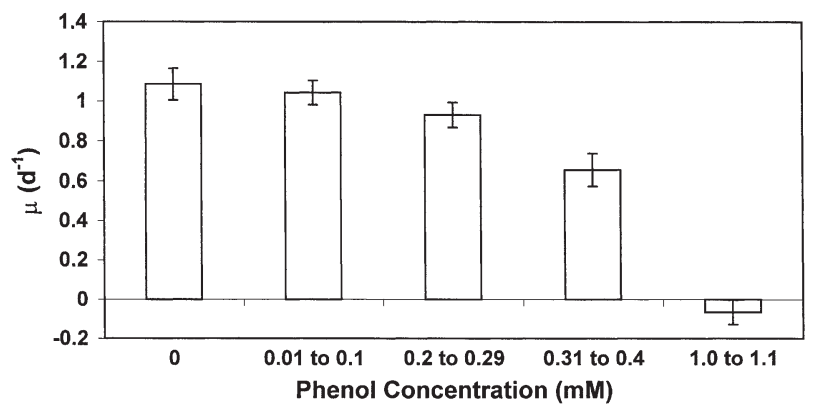

Fig. 3. Thalassiosira sp. Specific growth rate $(\mu)$ of replicate cultures grown without phenol $(0 \mathrm{mM})$ or with phenol added at different concentration ranges 
Table 1. Thalassiosira sp. Ring cleavage dioxygenase specific activities in cell-free extracts from cultures grown with different phenolic supplemental carbon sources. Cat 1,2- $\mathrm{O}_{2}$ ase: catechol 1,2-dioxygenase; Cat 2,3- $\mathrm{O}_{2}$ ase: catechol 2,3-dioxygenase; Proto 3,4- $\mathrm{O}_{2}$ ase: protocatechuate 3,4-dioxygenase; Proto 4,5- $\mathrm{O}_{2}$ ase: protocatechuate 4,5-dioxygenase. One unit of enzyme activity is defined as $1 \mu \mathrm{mol}$ of substrate consumed per minute

\begin{tabular}{|c|c|c|c|c|}
\hline \multirow[t]{2}{*}{ Substrate } & \multicolumn{4}{|c|}{ Specific activity ( $\mathrm{U} \mathrm{mg}^{-1}$ protein $)$} \\
\hline & Cat $1,2-\mathrm{O}_{2}$ ase & Cat $2,3-\mathrm{O}_{2}$ ase & Proto $3,4-\mathrm{O}_{2}$ ase & Proto $4,5-\mathrm{O}_{2}$ ase \\
\hline \multicolumn{5}{|l|}{ Expt A } \\
\hline None & 0 & 0 & 0 & 0 \\
\hline $1 \mathrm{mM}$ phenol & 0 & 0 & 0.40 & 0.16 \\
\hline $1 \mathrm{mM}$ catechol & \multicolumn{4}{|c|}{ Growth inhibited, therefore not measured } \\
\hline $1 \mathrm{mM}$ protocatechuate & \multicolumn{4}{|c|}{ Growth inhibited, therefore not measured } \\
\hline \multicolumn{5}{|l|}{ Expt B } \\
\hline None & 0 & 0 & 0 & 0 \\
\hline $1 \mathrm{mM}$ phenol & \multicolumn{4}{|c|}{ Growth inhibited, therefore not measured } \\
\hline $1 \mathrm{mM}$ benzoate & 0 & 0 & 0 & 0.11 \\
\hline
\end{tabular}
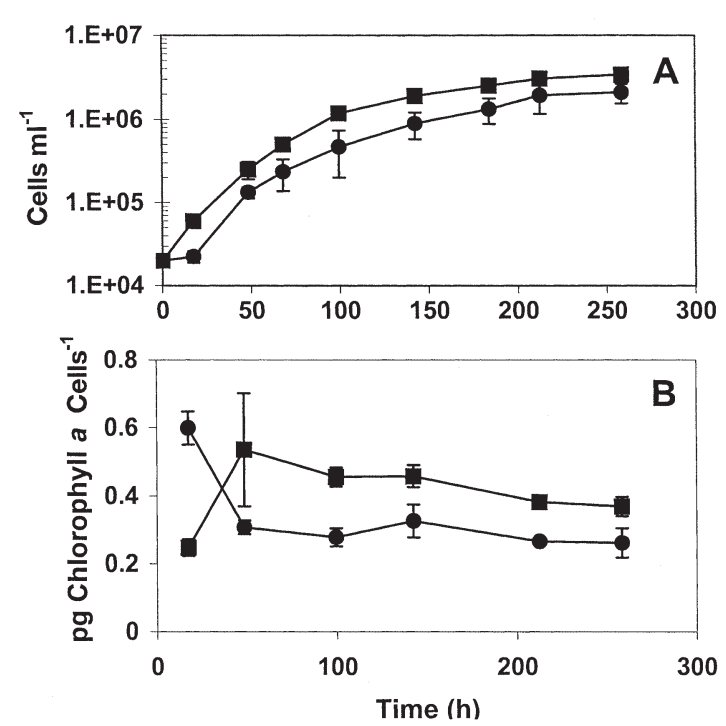

Fig. 4. Thalassiosira sp. Time-course changes in (A) cell abundance and (B) chlorophyll a cell ${ }^{-1}$ of cultures grown without phenol addition (control, $\mathbf{~})$ or with $0.25 \mathrm{mM}$ phenol

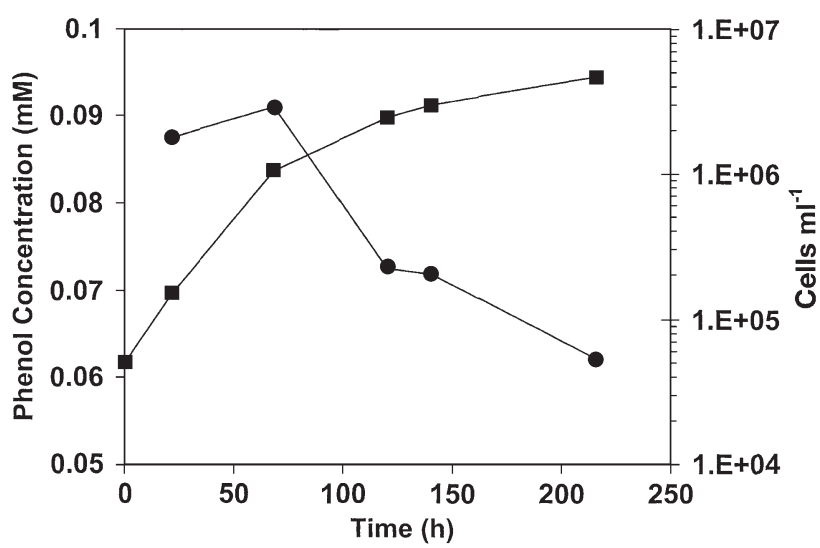

Fig. 5. Thalassiosira sp. Time-course changes in (匹) cell abundance and $(\bullet)$ culture medium phenol concentration in culture grown with $0.1 \mathrm{mM}$ phenol initial concentration phenol produced substantial levels of protocatechuate 3,4-dioxygenase and protocatechuate 4,5-dioxygenase, the ortho- and meta-pathway aromatic ring cleavage enzymes, respectively (Table 1). Only protocatechuate 4,5-dioxygenase activity was detected in Thalassiosira sp. grown in the presence of $1 \mathrm{mM}$ benzoate. No ring cleavage dioxygenase enzyme activities were detectable in control cells grown without supplemental phenolic substrates, and no catechol cleavage dioxygenases were detected.

\section{Production of dechlorinase activity}

Phenol-supplemented Thalassiosira sp. was also capable of dechlorinating monochlorophenols, 3,5dichlorophenol, and 2,4,6-trichlorophenol (Table 2). These reactions were NADH-dependent and were not observed in control cultures grown without phenol. In addition, no volatile halogenated aromatic compounds were detected in control cells during HPLC assays.

Table 2. Thalassiosira sp. Reductive dechlorinase specific activities in cell-free extracts from cultures grown with phenol as supplemental carbon source. 2CP: 2-chlorophenol; 3CP: 3-chlorophenol; 4CP: 4-chlorophenol; 3,5-DCP: 3,5-dichlorophenol; TCP: 2,4,6-trichlorophenol; nd: not determined. One unit of enzyme activity is defined as $1 \mu \mathrm{mol}$ of substrate consumed per minute

\begin{tabular}{|lccccc|}
\hline \multirow{2}{*}{$\begin{array}{l}\text { Phenol } \\
\text { conc. }\end{array}$} & 2CP & 3CP & $4 \mathrm{CP}$ & $3,5 \mathrm{DCP}$ & $\mathrm{TCP}$ \\
\hline Expt A & & & & & \\
0 & 0 & 0 & 0 & 0 & 0 \\
$1 \mathrm{mM}$ & 2.2 & 0.3 & 3.8 & 0.4 & 3.5 \\
Expt B & & & & & \\
0 & 0 & 0 & 0 & 0 & 0 \\
$0.25 \mathrm{mM}$ & $\mathrm{nd}$ & $\mathrm{nd}$ & $\mathrm{nd}$ & $\mathrm{nd}$ & 5.0 \\
\hline
\end{tabular}




\section{DISCUSSION}

This study is the first to demonstrate phenol degradation and reductive dechlorination in a marine diatom. Thalassiosira sp. is a ubiquitous diatom genus in marine planktonic and benthic environments, and thus understanding its role in breakdown or biotransformation of phenolic compounds may have widespread relevance in estuaries and other coastal regions influenced by anthropogenic and biogenic sources of phenolic compounds. Although the physiological response to phenol additions and catabolic enzyme activities indicate phenol degradation by Thalassiosira sp., it is unclear whether substrate breakdown is strictly a function of detoxification or if the diatom also uses phenol as a carbon source for growth. Although phenol enrichment did not enhance growth in any of our experiments, it is possible that mixotrophic (i.e. inorganic and phenol $\mathrm{C}$ use) growth rates did not exceed photoautotrophic rates at the moderate growth irradiance used. Indeed, $0.25 \mathrm{mM}$ phenol addition decreased cellular chlorophylla content but not growth rate. Use of phenol as a supplemental carbon source could explain the maintenance of growth despite the reduction in photosynthetic potential.

Similar to previous work with the freshwater chrysophyte Ochromonas danica (Semple \& Cain 1996, 1997), phenol catabolism appeared to be inducible in Thalassiosira sp. (i.e. ring cleavage dioxygenase or dehalogenase activity was only detected in diatom cultures incubated with phenol or benzoate), and a lag occurred in population growth which varied positively with phenol concentration. Levels of ring cleavage dioxygenases produced by phenol- and benzoategrown Thalassiosira sp. were comparable to those observed in 4-hydroxybenzoate- and protocatechuategrown Rhizobium leguminosarum (Chen et al. 1984, Chen \& Lovell 1990, 1994) and in catechol-grown $O$. danica (Semple \& Cain 1996). The specific activities of these enzymes in phenol- and benzoate-grown Thalassiosira sp. are certainly consistent with the capacity to use aromatic compounds as supplemental carbon sources, and in fact exceed those found in some bacteria that can utilize various aromatic compounds as their sole carbon source for growth (Chen et al. 1993).

Thalassiosira sp. produced protocatechuate 4,5dioxygenase, the meta-cleavage enzyme for protocatechuate. Phenol-grown cultures also produced protocatechuate 3,4-dioxygenase, the ortho-cleavage enzyme. The meta-cleavage reactions are often considered rare in eucaryotes (Cain 1980, Jones et al. 1993, Middelhoven 1993), but have been identified in both microalgae (Semple \& Cain 1996) and higher plants (Kickuth 1970, Gramss \& Rudeschko 1998). The report by Semple \& Cain (1996) of catechol 2,3-dioxygenase activity in Ochromonas danica, was the first of a metacleavage activity in an alga. However, Thalassiosira sp. produced no catechol dioxygenase activities, regardless of the growth substrate. The protocatechuate 4,5-dioxygenase activity assayed in Thalassiosira sp. represents the first observation of this enzyme in an alga. This activity has been found previously in tissues of several vascular plants including Mendicago sativa (alfalfa), Sinapis alba (white mustard), Lepidium sativum (cress), and Scripus lacustris (rush) (Kickuth 1970, Gramss \& Rudeschko 1998). Occurrence of both orthoand meta-cleavage activities in Thalassiosira sp. is not unique to this organism. Several bacterial species, including Azomonas agilis, Azospirillum brasilense, Azospirillum lipoferum, Azotobacter vinelandii, and Rhizobium leguminosarum can also produce both enzymes (Chen \& Lovell 1990, Chen et al. 1993, and references therein). The advantage gained by Thalassiosira sp. or other organisms from simultaneous production of the ring cleavage dioxygenases required for 2 parallel aromatic degradation pathways is not known.

Crude extracts prepared from phenol-grown Thalassiosira sp. also catalyzed an NADH-dependent dechlorination of various chlorophenols. The products of this reaction were consistent with a reductive dehalogenation mechanism: ortho and para carbon-chloride bonds were highly susceptible to reduction, but little activity against meta substituents was observed. Various bacterial dehalogenation reactions have been shown to attack different substituent positions with very different affinities (Häggblom 1990, Mohn \& Tiedje 1992, Steward et al. 1995, Watson et al. 2000). In many cases, only carbon-halide bonds at a single aromatic ring position are susceptible to catalytic cleavage.

Ochromonas danica extracts did not oxidize 4chlorophenol or 2,4-dichlorophenol (Semple \& Cain 1996), while Thalassiosira sp. extracts did so. An explanation for this dichotomy can be found in the different enzyme activities expressed by these organisms. As a general rule, degradation of halogenated aromatic compounds does not proceed through the meta-cleavage pathway (Knackmuss 1981, Rojo et al. 1987, Pettigrew et al. 1991). The observation of suicide inhibition of catechol 2,3-dioxygenase by production of an acylchloride from 3-chlorocatechol (Bartels et al. 1984) has been used as an explanation for the failure of meta-pathway oxidation of these compounds. This inhibition process could occur in $O$. danica and prevent oxidation of haloaromatics by this organism. It would be possible for the reductive dechlorination reaction catalyzed by Thalassiosira sp. to produce phenol from chlorophenols prior to catabolism of the chlorophenol aromatic ring. This sequence of reactions would avoid the issue of suicide inhibition altogether. It is also possible that the protocatechuate 4,5-dioxygenase activity 
of Thalassiosira sp. is not as susceptible to suicide inhibition as some, but not all (Mars et al. 1997), catechol 2,3-dioxygenases. Determining the resistance of protocatechuate 4,5-dioxygenase to possible suicide inhibition will require purification of the enzyme, which was beyond the scope of the present study.

Due to the volatility, toxicity, and low solubility of these compounds, we did not attempt to grow Thalassiosira sp. on chlorophenols or to demonstrate complete oxidation of chlorophenols by Thalassiosira sp. cultures. However, our finding of both a potent reductive dechlorinase activity and aromatic ring cleavage enzymes in the same crude extracts certainly indicates that such a catabolic route is possible. If the dechlorinase and ring cleavage activities we have demonstrated for Thalassiosira sp. are broadly distributed among diatom and other microalgal species, they may contribute to the resistance of some natural benthic marine algal assemblages to halophenols (Steward et al. 1992).

Acknowledgements. We thank Adam Leaphart for his assistance with the dehalogenation and phenol assays. Thanks also to Harold Marshall, Aaron Shurtleff, and Jennifer Wolny for identification of Thalassiosira $\mathrm{sp}$. This research was supported by EPA grant R82-4776-010 to C.R.L., and NSF Grants OCE-9315663 and DEB-9509057, and NOAA Grant NA90AA-D-SG672 to A.J.L. This is contribution number 1293 of the Belle W. Baruch Institute for Marine Biology and Coastal Research and contribution number 477 of the South Carolina Department of Natural Resources Marine Resources Research Institute.

\section{LITERATURE CITED}

Ahlborg UG, Thunberg TM (1980) Chlorinated phenols: occurrence, toxicity, metabolism, and environmental impact. Crit Rev Toxicol 7:1-35

Bartels I, Knackmuss HJ, Reineke W (1984) Suicide inactivation of catechol 2,3-dioxygenase from Pseudomonas putida mt-2 by 3-halocatechols. Appl Environ Microbiol 47: 500-505

Butler A, Walker JV (1993) Marine haloperoxidases. Chem Rev 93:1937-1944

Cain RB (1980) The uptake and metabolism of lignin-related aromatic compounds and their regulation in microorganisms. In: Kirk TK, Higuchi T, Chang HM (eds) Lignin biodegradation: microbiology, chemistry, and potential applications, Vol. 1. CRC Press, Boca Raton, FL, p 21-60

Chapman PM, Paine MD, Arthur AD, Taylor LA (1996) A triad study of sediment quality associated with a major, relatively untreated marine sewage discharge. Mar Pollut Bull 32:47-64

Chen YP, Lovell CR (1990) Purification and properties of catechol 1,2-dioxygenase from Rhizobium leguminosarum biovar viceae USDA 2370. Appl Environ Microbiol 56: 1971-1973

Chen YP, Lovell CR (1994) Purification and properties of a homodimeric protocatechuate 4,5-dioxygenase from Rhizobium leguminosarum. Arch Microbiol 161:191-195
Chen YP, Dilworth MJ, Glenn AR (1984) Aromatic metabolism in Rhizobium trifolii-protocatechuate 3,4-dioxygenase. Arch Microbiol 138:187-190

Chen YP, Lincoln DE, Woodin SA, Lovell CR (1991) Purification and properties of a unique flavin-containing chloroperoxidase from the capitellid polychaete Notomastus lobatus. J Biol Chem 266:23909-23915

Chen YP, Lopez-de-Victoria G, Lovell CR (1993) Utilization of aromatic compounds as carbon and energy sources during growth and $\mathrm{N}_{2}$-fixation by free-living nitrogen fixing bacteria. Arch Microbiol 159:207-212

Fielman KT, Woodin SA, Walla MD, Lincoln DE (1999) Widespread occurrence of natural halogenated organics among temperate marine infauna. Mar Ecol Prog Ser 181:1-12

Frost BW (1972) Effects of size and concentration of food particles on the feeding behavior of the marine planktonic copepod Calanus pacificus. Limnol Oceanogr 17:805-815

Fujisawa H (1970) Protocatechuate 3, 4-dioxygenase (Pseudomonas). Methods Enzymol 17A:526-529

Gedde A (1999) Thalassiosira andamanica sp. nov. (Bacillariophyceae), a new diatom from the Andaman Sea (Thailand). J Phycol 35:198-205

Glover HE, Morris I (1979) Photosynthetic carboxylating enzymes in marine phytoplankton. Limnol Oceanogr 23: 510-519

Goni MA, Thomas KA (2000) Sources and transformations of organic matter in surface soils and sediments from a tidal estuary (North Inlet, South Carolina, USA). Estuaries 23: 548-564

Gramss GG, Rudeschko O (1998) Activities of oxidoreductase enzymes in tissue extracts and sterile root exudates of three crop plants, and some properties of the peroxidase component. New Phytol 138:401-409

Gribble GW (1999) The diversity of naturally occurring organobromine compounds. Chem Soc Rev 28:335-346

Guillard RRL (1975) Culture of phytoplankton for feeding marine invertebrates. In: Smith WL, Chanley MH (eds) Culture of marine invertebrates. Plenum Press, New York, p 29-60

Häggblom MM (1990) Mechanisms of bacterial degradation and transformation of chlorinated monoaromatic compounds. J Basic Microbiol 30:115-141

Häggblom MM, Salkinoja-Salonen MS (1991) Biodegradability of chlorinated organic compounds in pulp bleaching effluents. Water Sci Technol 24:161-170

Jones KH, Trudgill PW, Hopper DJ (1993) Metabolism of $p$-cresol by the fungus Aspergillus fumigatus. Appl Environ Microbiol 59:1125-1130

Karickhoff SW, Brown DS, Scott TA (1979) Sorption of hydrophobic pollutants on natural sediments. Water Res 13: 241-248

Kickuth R (1970) Ökochemische Leistungen höherer Pflanzen. Naturwissenschaften 57:55-61

King GM (1986) Inhibition of microbial activity in marine sediments by a bromophenol from a hemichordate. Nature 323:257-259

Knackmuss HJ (1981) Degradation of halogenated and sulfonated hydrocarbons. In: Leisinger T, Cook AM, Hütter R, Nüesch J (eds) Microbial degradation of xenobiotics and recalcitrant compounds. Academic Press, London, p 189-212

Kringstad KP, Lindström K (1984) Spent liqours from pulp bleaching. Environ Sci Technol 18:236A-248A

Lewitus AJ, Kana TM (1994) Responses of estuarine phytoplankton to exogenous glucose: stimulation versus inhibition of photosynthesis and respiration. Limnol Oceanogr 39:182-189 
Lewitus AJ, Koepfler ET, Morris JT (1998) Seasonal variation in the regulation of phytoplankton by nitrogen and grazing in a salt-marsh estuary. Limnol Oceanogr 43:636-646

Lincoln DE, Fielman KT, Marinelli RL, Woodin SA (2002) Bromophenol accumulation and sediment contamination by the marine annelids Notomastus lobatus and Thelepus crispus. J Chem Ecol (in press)

Lowry OH, Rosebrough NJ, Farr AL, Randall RJ (1951) Protein measurement with the Folin phenol reagent. J Biol Chem 193:265-275

Mars AE, Kasberg T, Kaschabek SR, van Agteren MH, Janssen DB, Reineke W (1997) Microbial degradation of chloroaromatics: use of the meta cleavage pathway for mineralization of chlorobenzene. J Bacteriol 179:4530-4537

Middelhoven WJ (1993) Catabolism of benzene compounds by ascomycetous and basidiomycetous yeasts and yeastlike fungi. Antonie Leeuwenhoek 63:125-144

Mohn WW, Tiedje JM (1992) Microbial reductive dehalogenation. Microbiol Rev 56:482-507

Motamed B, Texier H (2000) Sources and characteristics of phenolic compounds in the Seine estuary (France). Oceanol Acta 23:167-174

Nakazawa T, Nakazawa A (1970) Pyrocatechase (Pseudomonas). Methods Enzymol 17A:518-522

Nozaki M (1970) Metapyrocatechase (Pseudomonas). Methods Enzymol 17A:522-525

Ono K, Nozaki M, Hayaishi O (1970) Purification and some properties of protocatechuate 4,5-dioxygenase. Biochim Biophys Acta 22:224-238

Pettigrew CA, Haigler BE, Spain JC (1991) Simultaneous biodegradation of chlorobenzene and toluene by a Pseudomonas strain. Appl Environ Microbiol 57:157-162

Porter KG, Feig Y (1980) The use of DAPI for identifying and counting aquatic microflora. Limnol Oceanogr 25:943-948

Reisch MS (1994) Top 50 chemicals production rose modestly last year. Chem Eng News 72:12-15

Rojo F, Pieper DH, Engesser KH, Knackmuss HJ, Timmis KN (1987) Assemblage of ortho cleavage route for simultaneous degradation of chloro- and methylaromatics. Science 238:1395-1398

Round F, Crawford R, Mann D (1990) The diatoms: biology and morphology of the genera. Cambridge University Press, Cambridge

Editorial responsibility: Otto Kinne (Editor),

Oldendorf/Luhe, Germany
Schellenberg K, Leuenberger C, Schwarzenbach RP (1984) Sorption of chlorinated phenols by natural sediments and aquifer materials. Environ Sci Technol 18:652-657

Semple KT, Cain RB (1996) Biodegradation of phenols by the alga Ochromonas danica. Appl Environ Microbiol 62: 1265-1273

Semple KT, Cain RB (1997) Degradation of phenol and its methylated homologues by Ochromonas danica. FEMS Microbiol Lett 152:133-139

Semple KT, Cain RB, Schmidt S (1999) Biodegradation of aromatic compounds by microalgae. FEMS Microbiol Lett 170:291-300

Steward CC, Pinckney J, Piceno Y, Lovell CR (1992) Bacterial numbers and activity, microalgal biomass and productivity and meiofaunal distribution in sediments naturally contaminated with biogenic bromophenols. Mar Ecol Prog Ser 90:61-72

Steward CC, Dixon TC, Chen YP, Lovell CR (1995) Enrichment and isolation of a reductively debrominating bacterium from the burrow of a bromometabolite producing marine hemichordate. Can J Microbiol 41:637-642

Tikoo V, Scragg AH, Shales SW (1997) Degradation of pentachlorophenol by microalgae. J Chem Tech Biotechnol 68: 425-431

Watson J, Matsui GY, Leaphart A, Rainey FA, Wiegel J, Lovell CR (2000) Reductively debrominating strains of Propionigenium maris from burrows of bromophenol producing marine infauna. Int J Syst Evol Microbiol 50:1035-1042

Wilson JO, Buchsbaum R, Valiela I, Swain T (1986) Decomposition in salt marsh ecosystems: phenolic dynamics during decay of litter of Spartina alterniflora. Mar Ecol Prog Ser 29:177-187

Woodin SA (1991) Recruitment of infauna: positive or negative cues? Am Zool 31:797-807

Woodin SA, Walla MD, Lincoln DE (1987) Occurrence of brominated compounds in soft-bottom benthic organisms. J Exp Mar Biol Ecol 107:209-217

Woodin SA, Marinelli R, Lincoln DE (1993) Allelochemical inhibition of recruitment in a sedimentary assemblage. J Chem Ecol 19:517-530

Xie TM, Abrahamsson K, Fogelqvist E, Josefsson B (1986) Distribution of chlorophenolics in a marine environment. Environ Sci Technol 20:457-463

Submitted: June 30, 2000; Accepted: August 14, 2001 Proofs received from author(s): February 27, 2002 